\title{
Impact of alternative sanitizers on the physicochemical quality, chlorophyll content and bioactive compounds of fresh vegetables
}

\author{
Kaio Henrique Cesconetto COSWOSCK ${ }^{1}$, Mylena Augustinho GIORGETTE ${ }^{1}$, Bárbara Morandi LEPAUS², \\ Erika Madeira Moreira da SILVA², Geralda Gillian Silva SENA ${ }^{1}$, Mariana Corrêa de Almeida AZEVEDO ${ }^{3}$, \\ Jackline Freitas Brilhante de SÃO JOSÉ2 ${ }^{2}$ (D)
}

\begin{abstract}
This study aimed to evaluate the effects of different sanitization solutions on the physicochemical characteristics of strawberries, cucumbers, and rocket leaves. In each procedure, $200 \mathrm{~g}$ of the sample was immersed in $1 \mathrm{~L}$ of sanitizing solution for 5 minutes. Strawberries, cucumbers and rocket leaves were sanitized with acetic, and lactic acid (1\% and 2\%), hydrogen peroxide (3\%), sodium hypochlorite and sodium dichloroisocyanurate $(200 \mathrm{mg} / \mathrm{L})$. Samples not submitted to sanitization were used as controls. The values of $\mathrm{pH}$, total titratable acidity, total soluble solids, vitamin $\mathrm{C}$ content, total phenolic compounds, and antioxidant capacity were directly analyzed, and chlorophyll (SPAD Index) was indirectly analyzed. Sanitized strawberries and cucumbers presented no significant difference ( $\mathrm{p}>0.05)$ in $\mathrm{pH}$ values, total titratable acidity, and total soluble solids/total titratable acidity ratio compared with un-sanitized samples. Vitamin $\mathrm{C}$ content was preserved in samples treated with sodium hypochlorite. All vegetables maintained their total phenolic compounds after sanitization treatments. The proposed treatments did not alter the physicochemical characteristics of the samples.
\end{abstract}

Keywords: organic acid; peroxide hydrogen; chlorine; quality; fresh-cut.

Practical Application: This paper contributes to investigate alternatives in the sanitization step of fruits and vegetables based on their physicochemical quality.

\section{Introduction}

In recent years, consumers have been looking to purchase more fresh fruits and vegetables in an attempt to increase the percentage of low-processed food and decrease the percentage of ready-to-eat foods they consume, but they have concerns about the sensorial quality and nutritional value of fresh produce (Singh et al., 2018).

Processing increases the perishability of food products due to increased metabolic activity and enzymes and substrates decompartmentalization, resulting in browning, loss of firmness, and the development of unpleasant flavours (Ranjitha et al., 2018). Owing to high water content, vegetables and fruits are highly perishable foods and show short post-harvest shelf lives. To extend their shelf lives, it is necessary to know and use appropriate handling practices during harvest, post-harvest, storage, transport, distribution, commercialization, and consumption, since microbial contamination can occur during any of these steps (Lopez et al., 2018; Singh et al., 2018).

Washing procedures and sanitizing solutions are considered sufficient to decrease the number of deteriorating and pathogenic microorganisms, provide more security, and improve the shelf lives of the products. In the case of minimally processed and fresh products, sanitization is an essential step in imparting additional security and extending shelf life. For the food industry, chlorine-based sanitizing reagents are the most commonly used (São José et al., 2014; Mishra et al., 2018). While using chlorinated compounds is an option, there may be restrictions on their use in the future (Rosário et al., 2017; Mishra et al., 2018). The use of based chlorine compounds in the sanitization of fruits and vegetables has already been prohibited in several European countries such as Germany, Belgium, Holland, and Sweden (Shahbaz et al., 2018). Thus, identification of alternative methods that can efficiently reduce microbial contamination of rinse water and minimally processed products is important.

A proposed alternative sanitizing agent is hydrogen peroxide (São José \& Vanetti, 2015; Zhang \& Yang, 2017). It is a well-known germicidal agent, and it is not environmentally aggressive due to its low toxicity (Alexandre et al., 2012). Another option for sanitizing is organic acid, such as acetic acid or lactic acid (Tian et al., 2013; Valiolahi et al., 2019), which are natural constituents of many foods and are widely used as additives for food preservation. Such as hydrogen peroxide, they are generally recognized as safe (GRAS) and commonly used due to their antimicrobial activity (Park et al., 2009).

New sanitization treatments should be evaluated not only for their ability to control pathogenic and deterioration-causing microorganisms but also for their impact on the chemical and 
sensorial characteristic of vegetables and fruits. Considering the interest in methods for fruit and vegetable sanitization that are not based on the use of the chlorinated compound, the aim of this study was to evaluate the impact of these alternative treatments on the physicochemical characteristics of strawberries (Fragaria $\times$ ananassa), cucumbers (Cucumis sativus) and rocket leaves (Eruca sativa).

\section{Materials and methods}

\subsection{Obtaining samples}

Vegetables with different vegetal structures (susceptible vegetable tissue, hard vegetable tissue, and leafy) were chosen to develop this study, allowing for a broader evaluation of the impact of these sanitizing agents on vegetable matter.

Strawberries, cucumbers and rocket leaves were purchased at local markets of Vitória (Espírito Santo State, Brazil) and transported in isothermal boxes to the analysis laboratory of the Pharmaceutical Science Department of Federal University of Espírito Santo. The samples were kept at $7{ }^{\circ} \mathrm{C}$ for a maximum of 24 hours before the analysis. Next, the vegetables with deformities, that were damaged or that had begun to putrefy were discarded. The selected were washed with running water to remove surface-adhered dirt and were then drained for 10 minutes.

\subsection{Sanitization treatments}

The sanitizing agents evaluated were $1 \%$ and $2 \%$ lactic acid (Neon ${ }^{\circledR}$, Suzano, São Paulo, Brazil), $1 \%$ and $2 \%$ acetic acid (Fmaia ${ }^{\circledR}$, Belo Horizonte, Minas Gerais, Brazil), and 3\% hydrogen peroxide (Êxodo Científica ${ }^{\circledR}$, Hortolândia, São Paulo, Brazil). For comparison, two commonly used chlorinated compounds, sodium hypochlorite (Hidrosteril ${ }^{\circledR}$, Itapevi, São Paulo, Brazil) and sodium dichloroisocyanurate (NippoClor Nippon ${ }^{\circledR}$, Indaiatuba, São Paulo, Brazil), were also tested. Both chlorine sanitizing agents were used at concentrations of $200 \mathrm{mg} / \mathrm{L}$. Samples not submitted to sanitization were used as controls. In each procedure, $200 \mathrm{~g}$ of the sample was immersed in $1 \mathrm{~L}$ of sanitizing solution for 5 minutes. The concentration of sanitizing solutions was chosen based on previous studies.

After sanitization, the chemical characteristics of the samples were evaluated. These analyses aimed to identify possible changes in quality after sanitization treatments.

\subsection{Physicochemical analyses}

Total titratable acidity, $\mathrm{pH}$, total soluble solids and TTS/TSS ratio

Total titratable acidity (TTA), $\mathrm{pH}$, total soluble solids (TSS), and TTS/TSS ratio were analysed according to the method described by Instituto Adolfo Lutz (Instituto Adolfo Lutz, 2008). Results of TTA were expressed as \% citric acid. pH determination were made using a pH meter (Digimed DM 20, São Paulo, Brazil). Total soluble solids were determined using an analogic refractometer (Instrutherm ${ }^{\circledR}$, model RT-10ATC, São Paulo, Brazil). Readings were made at $25^{\circ} \mathrm{C}$ with three drops of pulp derived from $10 \mathrm{~g}$ of homogenized sample. The results were expressed in ${ }^{\circ}$ Brix.

\section{Chlorophyll content}

Indirect determination of chlorophyll (SPAD index) was determined for rocket leaves. Readings were performed with a chlorophyll meter (Minolta ${ }^{\circledR}$, model SPAD-502, Osaka, Japan), and results were expressed in SPAD units. Chlorophyll levels were tested at 6 points on rocket leaves after sanitization. In this procedure part of the light that reaches the leaf is absorbed by chlorophyll, and the other part reaches the detector cell equipment and is converted into an electrical signal. The amount of light captured by this cell is inversely proportional to the amount of light captured by the chlorophyll. The amount of light captured by the equipment is processed, and the absorbance is quantified in dimensional values ranging from 0 to 1999 SPAD units, in which larger values indicate greener leaves (Argenta et al., 2001).

Vitamin C (ascorbic acid), phenolic compounds and antioxidant capacity

For Vitamin C (ascorbic acid) evaluation, samples were titrated with 2,6-dichlorophenolindophenol based on the procedure described by Association of Official Analytical Chemists (Association of Official Analytical Chemists, 1997). This analysis was not performed with cucumber samples due to their low vitamin C content, which made difficult to use this method.

Total phenolic compounds were estimated using the Folin-Ciocalteu reagent (Sigma Aldrich ${ }^{\circledR}$, St. Louis, Missouri, USA) using the procedure described by Singleton et al. (1999). Once the samples were prepared, readings were taken using the spectrophotometer model UV - 2000A (Instrutherm ${ }^{\circledR}$, São Paulo, Brazil) at $765 \mathrm{~nm}$. A calibration curve with generated from different Gallic acid concentrations was used $(Y=8,1625 x-0,0802$; $\left.\mathrm{R}^{2}=0,9845\right)$, and results were expressed as $\mathrm{mg}$ Gallic acid equivalent/100 g.

The effect of sanitizing treatments on antioxidant capacity was evaluated using 1,1-diphenyl-2-picrylhydrazyl (DPPH) (Sigma Aldrich $^{\circledR}$, St. Louis, Missouri, USA), according to the method described by Blois (1958). Readings were taken using a spectrophotometer model UV - 2000A (Instrutherm ${ }^{\circledR}$, São Paulo, Brazil) at $517 \mathrm{~nm}$. The free radical-scavenging (DPPH) activity was calculated according to Equation 1.

DPPH activity $(\%)=100 \%-\{($ sampleAbs - white sampleAbs / controlAbs $) \times 100\}$

Where controlAbs is the absorbance of the control (DPPH solution without samples); sampleAbs is the absorbance of the test sample (DPPH solution with test sample); and white sample Abs is the absorbance of only extraction solution, without samples or DPPH solution.

\section{Experimental design and Statistical analyses}

The experiments were conducted in a completely randomized design and were performed in three replicates with triplicates of each analysis. The results were subjected to analysis of variance 
(ANOVA) using the Infostat ${ }^{\circledR}$ software. Means were compared by Tukey's Test, at $5 \%$ level of probability.

\section{Results and discussion}

\subsection{Evaluation of the physicochemical characteristics and chlorophyll content after different sanitization procedures}

\section{Strawberries}

The evaluation of the impact of sanitizers on strawberries (Table 1) showed that there were no significant differences in $\mathrm{pH}$, total titratable acidity, total soluble solids, or the total soluble solids/total titratable acidity ratio (TSS/TTA) with any of the treatments studied. This indicates the preservation of these characteristics even after sanitization treatments.

These results corroborate findings by Nogales-Delgado et al. (2013) who found that strawberry samples treated with sodium hypochlorite $100 \mathrm{mg} / \mathrm{L}$ and lactic acid $2.5 \mathrm{~g} / \mathrm{L}$ did not show significant differences in total soluble solids, total titratable acidity or pH. Fernandes (2013) also verified that strawberries maintained their quality based on total soluble solids, total titratable acidity, TSS/TTA ratio, and firmness, after treatment with $1 \%$ lactic acid. However, São José \& Vanetti (2015) observed that application of $40 \mathrm{mg} / \mathrm{L}$ peracetic acid (a mixture of hydrogen peroxide and acetic acid) decreased the $\mathrm{pH}$ of strawberries and sanitizers such as $200 \mathrm{mg} / \mathrm{L}$ sodium dichloroisocyanurate and $5 \%$ hydrogen peroxide did not decrease $\mathrm{pH}$ of treated samples. In contrast, Nicolau-Lapeña et al. (2019) found lower values for $\mathrm{pH}$ and total soluble solids, and higher content of titratable acidity after sanitization of strawberries with $40 \mathrm{ppm}$ of peracetic acid.

Rosário et al. (2017) evaluated strawberries treated with different procedures and observed that the level of total soluble solid of samples sanitized with $0,8 \%$ acetic acid did not differ from samples that had not been sanitized. Alexandre et al. (2012) tested $200 \mu \mathrm{g} / \mathrm{mL}$ sodium hypochlorite, $1 \%$ and $5 \%$ hydrogen peroxide for strawberry sanitization and verified that treatments did not change $\mathrm{pH}$ values compared with fresh samples. Concerning the results of total titratable acidity and total soluble solids, Reis et al. (2008) observed that strawberry samples treated with $200 \mathrm{mg} / \mathrm{L}$ sodium dichloroisocyanurate and $10 \%$ hydrogen peroxide did not show any variation in total soluble solid values. However, they observed changes in total titratable acidity in the samples treated over the storage period.

The total soluble solids/total titratable acidity ratio is one of the most common indexes used to determine the maturation and palatability of fruits and corresponds to the sugar and acid contents, making it an appropriate parameter for measuring consumer's taste perception (Suarez et al., 2008). The maintenance of this index in strawberries sanitized by alternative treatments shows that this important characteristic has been preserved.

\section{Cucumbers}

The values of $\mathrm{pH}$, total titratable acidity and the ratio of total soluble solids/total titratable acidity of cucumber samples do not differ between sanitized and un-sanitized samples, $(\mathrm{p}>0.05)$, as shown in Table 2.

Cucumber samples treated with $2 \%$ lactic acid, sodium dichloroisocyanurate, and $200 \mathrm{mg} / \mathrm{L}$ sodium hypochlorite showed total soluble solid values statistically lower than those observed in non-sanitized samples. These results may indicate a loss of original vegetable characteristics due to treatments. However, mineral nutrition during vegetable planting is one of the factors that directly contribute to food productivity and quality.

Rosário et al. (2018) treated melon with sodium hypochlorite at $100 \mathrm{mg} / \mathrm{L}$ and observed preservation of $\mathrm{pH}$, total titratable acidity, and firmness of the samples. Studies with watermelons verified that potassium increased thickness and resistance of the rind and that this mineral may promote an increase in the total concentrations of soluble solids (Feitosa et al., 2009).

\section{Rocket leaves}

$\mathrm{pH}$ values of rocket leaf samples sanitized with $1 \%$ or $2 \%$ acetic acid or $1 \%$ or $2 \%$ lactic acid were lower than the $\mathrm{pH}$ levels observed in the control samples ( $\mathrm{p}<0.05)$ (Table 3$)$. These results may demonstrate that the immersion method for sanitizing these hardwood vegetables may have helped to incorporate the acid sanitizing solution and thus may have had an influence on $\mathrm{pH}$. The monitoring of this quality parameter after sanitizing is

Table 1. Mean values \pm standard deviation* of $\mathrm{pH}$, total soluble solids, total titratable acidity, total soluble solids/total titratable acidity ratio (TSS/TTA), ascorbic acid, phenolic compounds, and antioxidant capacity of strawberry samples treated with different sanitizers.

\begin{tabular}{|c|c|c|c|c|c|c|c|}
\hline Treatment & $\mathrm{pH}$ & TSS ( ${ }^{\circ}$ Brix) & $\begin{array}{c}\text { TTA (\% citric } \\
\text { acid) }\end{array}$ & TSS/TTA ratio & $\begin{array}{c}\text { Ascorbic acid } \\
(\mathrm{mg} / 100 \mathrm{~g})\end{array}$ & $\begin{array}{c}\text { Phenolic } \\
\text { compounds } \\
\text { (mg Gallic acid } \\
\text { equivalent/100 g) }\end{array}$ & $\begin{array}{l}\text { Antioxidant } \\
\text { capacity (\%) }\end{array}$ \\
\hline Non-sanitized & $3.31 \pm 0.08^{\mathrm{a}}$ & $7.13 \pm 0.68^{a}$ & $1.32 \pm 0.47^{\mathrm{a}}$ & $5.74 \pm 1.47^{\mathrm{a}}$ & $56.19 \pm 2.97^{\mathrm{a}}$ & $386.13 \pm 32.15^{\mathrm{a}}$ & $71.46 \pm 1.11^{\mathrm{a}}$ \\
\hline Acetic acid $1 \%$ & $3.31 \pm 0.08^{a}$ & $6.30 \pm 0.65^{\mathrm{a}}$ & $1.28 \pm 0.03^{\mathrm{a}}$ & $4.91 \pm 0.59^{\mathrm{a}}$ & $39.52 \pm 4.59^{\mathrm{b}}$ & $410.88 \pm 28.35^{\mathrm{a}}$ & $72.18 \pm 1.09^{\mathrm{a}}$ \\
\hline Acetic acid $2 \%$ & $3.31 \pm 0.12^{\mathrm{a}}$ & $6.58 \pm 0.06^{\mathrm{a}}$ & $1.42 \pm 0.30^{\mathrm{a}}$ & $4.76 \pm 0.92^{\mathrm{a}}$ & $38.57 \pm 5.15^{\mathrm{b}}$ & $383.13 \pm 5.19^{\mathrm{a}}$ & $72.29 \pm 3.83^{\mathrm{a}}$ \\
\hline Lactic acid $1 \%$ & $3.29 \pm 0.08^{a}$ & $6.80 \pm 0.83^{a}$ & $1.31 \pm 0.03^{\mathrm{a}}$ & $5.20 \pm 0.76^{\mathrm{a}}$ & $42.85 \pm 2.85^{\mathrm{b}}$ & $361.38 \pm 10.71^{\mathrm{a}}$ & $71.35 \pm 2.02^{\mathrm{a}}$ \\
\hline Lactic acid $2 \%$ & $3.23 \pm 0.05^{\mathrm{a}}$ & $6.18 \pm 0.34^{\mathrm{a}}$ & $1.40 \pm 0.21^{\mathrm{a}}$ & $4.45 \pm 0.42^{\mathrm{a}}$ & $54.76 \pm 4.12^{\mathrm{a}}$ & $379.94 \pm 10.74^{\mathrm{a}}$ & $72.49 \pm 1.43^{\mathrm{a}}$ \\
\hline Hydrogen peroxide $3 \%$ & $3.45 \pm 0.32^{\mathrm{a}}$ & $6.48 \pm 0.85^{\mathrm{a}}$ & $1.24 \pm 0.36^{\mathrm{a}}$ & $5.39 \pm 0.95^{\mathrm{a}}$ & $42.85 \pm 2.85^{\mathrm{b}}$ & $376.85 \pm 16.08^{\mathrm{a}}$ & $69.18 \pm 3.90^{\mathrm{a}}$ \\
\hline Sodium dichloroisocyanurate & $3.26 \pm 0.11^{\mathrm{a}}$ & $6.53 \pm 0.58^{\mathrm{a}}$ & $1.43 \pm 0.27^{\mathrm{a}}$ & $4.72 \pm 1.21^{\mathrm{a}}$ & $34.28 \pm 2.86^{\mathrm{b}}$ & $398.50 \pm 28.37^{\mathrm{a}}$ & $68.12 \pm 4.80^{\mathrm{a}}$ \\
\hline Sodium hypochlorite & $3.30 \pm 0.11^{\mathrm{a}}$ & $6.05 \pm 1.47^{\mathrm{a}}$ & $1.37 \pm 0.14^{\mathrm{a}}$ & $4.72 \pm 1.21^{\mathrm{a}}$ & $41.90 \pm 4.36^{\mathrm{b}}$ & $375.60 \pm 13.93^{\mathrm{a}}$ & $72.83 \pm 1.90^{\mathrm{a}}$ \\
\hline
\end{tabular}


Table 2. Mean values \pm standard deviation ${ }^{\star}$ of $\mathrm{pH}$, total soluble solids, total titratable acidity, total soluble solids/total titratable acidity ratio (TSS/TTA), phenolic compounds, and antioxidant capacity of cucumber samples treated with different sanitizers.

\begin{tabular}{|c|c|c|c|c|c|c|}
\hline Treatment & $\mathrm{pH}$ & $\begin{array}{c}\text { TSS } \\
\left({ }^{\circ} \text { Brix }\right)\end{array}$ & $\begin{array}{c}\text { TTA } \\
\text { (\% citric acid) }\end{array}$ & $\begin{array}{l}\text { TSS/TTA } \\
\text { ratio }\end{array}$ & $\begin{array}{c}\text { Phenolic } \\
\text { compounds } \\
\text { (mg Gallic acid } \\
\text { equivalent/100 g) }\end{array}$ & $\begin{array}{l}\text { Antioxidant } \\
\text { capacity } \\
(\%)\end{array}$ \\
\hline Acetic acid 1\% & $6.04 \pm 0.12^{\mathrm{a}}$ & $2.58 \pm 0.51^{\mathrm{abc}}$ & $0.95 \pm 0.22^{\mathrm{a}}$ & $2.76 \pm 0.63^{\mathrm{a}}$ & $26.37 \pm 2.92^{\mathrm{a}}$ & $27.81 \pm 1.10^{\mathrm{a}}$ \\
\hline Acetic acid 2\% & $6.01 \pm 0.10^{\mathrm{a}}$ & $2.66 \pm 0.50^{\mathrm{abc}}$ & $1.02 \pm 0.35^{\mathrm{a}}$ & $2.93 \pm 1.51^{\mathrm{a}}$ & $25.93 \pm 4.39^{\mathrm{a}}$ & $27.70 \pm 3.93^{\mathrm{a}}$ \\
\hline Lactic acid $1 \%$ & $6.02 \pm 0.14^{\mathrm{a}}$ & $2.96 \pm 0.07^{\mathrm{ab}}$ & $0.91 \pm 0.15^{\mathrm{a}}$ & $3.29 \pm 0.51^{\mathrm{a}}$ & $27.48 \pm 4.95^{\mathrm{a}}$ & $28.64 \pm 2.22^{\mathrm{a}}$ \\
\hline Hydrogen peroxide $3 \%$ & $6.15 \pm 0.17^{\mathrm{a}}$ & $2.83 \pm 0.22^{\mathrm{abc}}$ & $1.03 \pm 0.20^{\mathrm{a}}$ & $2.83 \pm 0.75^{\mathrm{a}}$ & $28.16 \pm 1.03^{\mathrm{a}}$ & $30.81 \pm 3.95^{\mathrm{a}}$ \\
\hline Sodium dichloroisocyanurate & $6.09 \pm 0.24^{\mathrm{a}}$ & $2.26 \pm 0.10^{c}$ & $0.82 \pm 0.15^{\mathrm{a}}$ & $2.86 \pm 0.69^{\mathrm{a}}$ & $24.70 \pm 3.52^{\mathrm{a}}$ & $27.16 \pm 1.92^{\mathrm{a}}$ \\
\hline Sodium hypochlorite & $6.12 \pm 0.10^{\mathrm{a}}$ & $2.31 \pm 0.31^{\mathrm{c}}$ & $0.91 \pm 0.33^{\mathrm{a}}$ & $3.29 \pm 1.35^{\mathrm{a}}$ & $28.13 \pm 5.13^{\mathrm{a}}$ & $28.95 \pm 1.57^{\mathrm{a}}$ \\
\hline
\end{tabular}

*Values followed by the same letter in the same column were not significantly different by Tukey's test at a $5 \%$ level of probability(p $>0.05)$. TSS: Total soluble solids; TTA: Total titratable acidity.

Table 3. Mean values \pm standard deviation* of $\mathrm{pH}$, total soluble solids, total titratable acidity, total soluble solids/total titratable acidity ratio (TSS/TTA), ascorbic acid, phenolic compounds, and antioxidant capacity of rocket leaf samples treated with different sanitizers.

\begin{tabular}{|c|c|c|c|c|c|c|c|}
\hline Treatment & $\mathrm{pH}$ & $\begin{array}{c}\text { TSS } \\
\left({ }^{\circ} \text { Brix }\right)\end{array}$ & $\begin{array}{c}\text { TTA } \\
\text { (\% citric acid) }\end{array}$ & $\begin{array}{l}\text { TSS/TTA } \\
\text { ratio }\end{array}$ & $\begin{array}{l}\text { Ascorbic acid } \\
(\mathrm{mg} / 100 \mathrm{~g})\end{array}$ & $\begin{array}{c}\text { Phenolic } \\
\text { compounds } \\
\text { (mg Gallic acid } \\
\text { equivalent } / 100 \mathrm{~g} \text { ) }\end{array}$ & $\begin{array}{l}\text { Antioxidant } \\
\text { capacity } \\
(\%)\end{array}$ \\
\hline Non-sanitized & $6.20 \pm 0.16^{\mathrm{a}}$ & $4.16 \pm 0.60^{\mathrm{ab}}$ & $1.18 \pm 0.39^{\mathrm{b}}$ & $3.65 \pm 0.73^{\mathrm{a}}$ & $109.00 \pm 8.66^{\mathrm{a}}$ & $82.42 \pm 3.43^{\mathrm{a}}$ & $76.40 \pm 10.03^{\mathrm{ab}}$ \\
\hline Acetic acid 1\% & $4.71 \pm 0.24^{\mathrm{b}}$ & $2.85 \pm 0.22^{\mathrm{b}}$ & $3.64 \pm 0.51^{\mathrm{a}}$ & $2.78 \pm 0.06^{\mathrm{a}}$ & $90.66 \pm 5.03^{b}$ & $67.29 \pm 4.71^{\mathrm{a}}$ & $75.21 \pm 4.50^{\mathrm{ab}}$ \\
\hline Acetic acid $2 \%$ & $4.64 \pm 0.37^{\mathrm{b}}$ & $3.63 \pm 0.23^{\mathrm{ab}}$ & $4.33 \pm 1.52^{\mathrm{a}}$ & $2.90 \pm 0.20^{\mathrm{a}}$ & $83.00 \pm 4.58^{\mathrm{b}}$ & $69.57 \pm 8.32^{\mathrm{a}}$ & $87.74 \pm 1.01^{\mathrm{a}}$ \\
\hline Lactic acid $1 \%$ & $4.69 \pm 0.19^{b}$ & $3.18 \pm 0.12^{\mathrm{ab}}$ & $2.07 \pm 0.73^{\mathrm{a}}$ & $1.73 \pm 0.83^{\mathrm{a}}$ & $89.00 \pm 7.55^{\mathrm{b}}$ & $74.20 \pm 6.92^{\mathrm{a}}$ & $79.58 \pm 4.03^{\mathrm{ab}}$ \\
\hline Lactic acid $2 \%$ & $4.37 \pm 0.16^{\mathrm{b}}$ & $3.13 \pm 0.10^{\mathrm{ab}}$ & $3.48 \pm 0.45^{\mathrm{a}}$ & $2.91 \pm 0.12^{\mathrm{a}}$ & $78.66 \pm 7.23^{\mathrm{b}}$ & $74.25 \pm 8.15^{\mathrm{a}}$ & $77.12 \pm 0.12^{\mathrm{ab}}$ \\
\hline Hydrogen peroxide 3\% & $6.06 \pm 0.69^{\mathrm{a}}$ & $4.33 \pm 1.22^{\mathrm{ab}}$ & $1.45 \pm 0.43^{\mathrm{b}}$ & $3.37 \pm 1.97^{\mathrm{a}}$ & $75.66 \pm 7.64^{\mathrm{b}}$ & $71.87 \pm 3.65^{\mathrm{a}}$ & $52.97 \pm 3.51^{\mathrm{c}}$ \\
\hline Sodium dichloroisocyanurate & $6.25 \pm 0.22^{\mathrm{a}}$ & $4.63 \pm 1.45^{\mathrm{a}}$ & $1.37 \pm 0.33^{\mathrm{b}}$ & $3.51 \pm 1.55^{\mathrm{a}}$ & $75.66 \pm 8.50^{\mathrm{b}}$ & $72.05 \pm 5.76^{\mathrm{a}}$ & $77.06 \pm 4.52^{\mathrm{ab}}$ \\
\hline Sodium hypochlorite & $6.41 \pm 0.23^{\mathrm{a}}$ & $3.87 \pm 1.01^{\mathrm{ab}}$ & $1.36 \pm 0.38^{\mathrm{b}}$ & $2.99 \pm 1.26^{\mathrm{a}}$ & $90.00 \pm 6.00^{\mathrm{ab}}$ & $73.56 \pm 7.69^{a}$ & $67.61 \pm 1.97^{\mathrm{b}}$ \\
\hline
\end{tabular}

*Values followed by the same letter in the same column were not significantly different by Tukey’s test at a $5 \%$ level of probability(p $>0.05)$. TSS: Total soluble solids; TTA: Total titratable acidity.

relevant because some sanitizers promote changes in vegetable $\mathrm{pH}$, thereby accelerating product deterioration (Rico et al., 2007).

São José \& Vanetti (2015) observed that watercress and parsley samples treated with running water, hydrogen peroxide, and peracetic acid showed significantly lower $\mathrm{pH}$ values. Silveira et al. (2018) treated fresh lettuce with peracetic acid and observed a reduction of the $\mathrm{pH}$ after sanitization.

Total soluble solid values of samples treated with $1 \%$ acetic acid were lower $(\mathrm{p} \leq 0.05)$ than the TSS values of the samples treated with sodium dichloroisocyanurate treatment. This parameter is related to the state of food conservation since most cases of food decomposition promote changes in hydrogen ion concentration (Instituto Adolfo Lutz, 2008) and influence food sensorial characteristics.

There were no significant differences for SPAD index ( $p>0.05)$, which indicates chlorophyll content was preserved after sanitization (Figure 1). An average value of 34.85 units was observed. This is a satisfactory result since chlorophyll loss is a relevant factor in vegetable quality. Degradation of this compound may causes changes in colour. The evaluation of chlorophyll content is one of the most effective parameters in determining post-harvest quality, which indicates age in hardwood vegetables, in addition to providing information such as degree of maturity and conservation status (Silva et al., 2007).

Gutiérrez et al. (2015) evaluated the effect of UV-C radiation on chlorophyll content by spectrophotometric analysis and found divergent results, with 18 to $21 \%$ of chlorophyll content degraded after sanitization treatment. Karaca \& Velioglu (2014) found that in hardwood vegetables (lettuce, spinach, and parsley) sanitization procedures with ozone and chlorinated water did not promote a significant reduction in chlorophyll content. Nguyen et al. (2019) did not find differences in the chlorophyll content of baby spinach after sanitization with $75 \mathrm{mg} / \mathrm{L}$ of peracetic acid. However, Martínez-Sánchez et al. (2006) found significant differences in the chlorophyll contents of rocket leaves after sanitization with $20 \mathrm{ml} / \mathrm{L}$ lactic acid, $100 \mathrm{mg} / \mathrm{L}$ sodium hypochlorite, $10 \mathrm{mg} / \mathrm{L}$ ozone or $300 \mathrm{ml} / \mathrm{L}$ peracetic acid.

\section{Evaluation of ascorbic acid, total phenolic compounds, and antioxidant capacity}

Ascorbic acid content was reduced in all sanitized strawberry samples compared to non-sanitized samples ( $p<0.05)$, except for the samples treated with $2 \%$ lactic acid solution, for which the vitamin content was not affected (Table 1). Strawberries have 


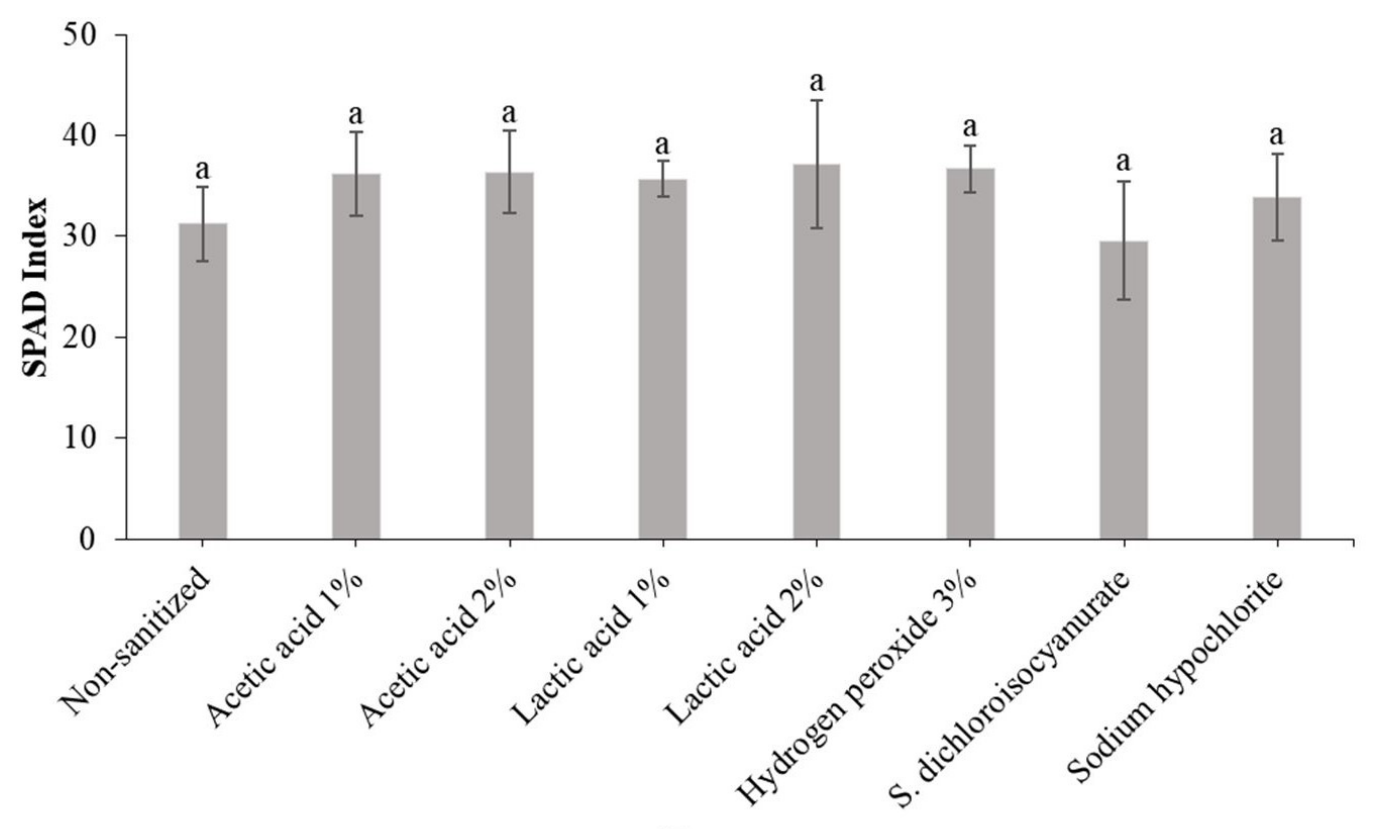

Treatment

Figure 1. Indirect determination of chlorophyll (SPAD index) of rocket leaf samples treated.

high vitamin C levels, and according to Musa et al. (2015), this amount may vary depending on variety, cultivation system, fruit maturity, post-harvest weather conditions, and post-harvest management. Alexandre et al. (2012) evaluated non-thermal technologies such as ozone, ultrasound, ultraviolet-C radiation, sodium hypochlorite solution, and hydrogen peroxide for sanitizing strawberries and observed that all sanitized samples showed higher ascorbic acid contents compared to non-treated samples or those only washed with water.

There was no ascorbic acid content reduction in rocket leaf samples sanitized with sodium hypochlorite compared to non-sanitized samples $(\mathrm{p}<0.05)$ (Table 3$)$. This indicates that this nutrient level was preserved in samples submitted to this treatment. However, for the other treatments, this vitamin level was reduced by treatment with a sanitizing agent. Martínez-Sánchez et al. (2006) observed a significant reduction in ascorbic acid content only in samples sanitized with $20 \mathrm{ml} / \mathrm{L}$ of lactic acid-based solution, among other sanitizing processes. A study with basil leaves (Valiolahi et al., 2019) demonstrated losses of ascorbic acid content after sanitization with acetic and lactic acid (2\%), $\mathrm{NaCl}(7 \%)$ and hydrogen peroxide (1 and 2\%).

Ascorbic acid is a very unstable vitamin, and its content may be affected by heat, oxygen, and light. Moreover, the type of washing (still or turbulent water) can cause mechanical stress and a loss of the nutrient (Dewhirst et al., 2017). For this reason, it's important to evaluate all parameters in the determination of a sanitization treatment.

In the evaluation of the impact of sanitizers on the level of total phenolic compounds in strawberries (Table 1), cucumbers (Table 2) and rocket leaves (Table 3), it was observed that no significant difference existed between sanitized and nonsanitized samples. This means the nutritional characteristics of the vegetables were preserved after the sanitizing treatments.
Martínez-Sánchez et al. (2006) also did not observe significant differences in rocket leaves treated with different sanitizing agents (chlorinated compounds, ozone, lactic acid, acidified chlorinated solution, and peracetic acid). Phenolic compounds are important antioxidants in human nutrition (Park \& Kim, 2015). In addition to that, the level of phenolic compounds in fruits and vegetables directly influences their sensorial characteristics (Martínez-Sánchez et al., 2006) since they can confer colour to the vegetable. These compounds may also prevent the oxidation of various nutrients, particularly lipids (Brand-Williams et al., 1995).

About antioxidant capacity, neither strawberry samples (Table 1) nor cucumber samples (Table 2) differed among themselves after each treatment $(p>0.05)$. Similar to the present study, Nicolau-Lapeña et al. (2019) did not found losses in total phenolic compounds, and antioxidant capacity after sanitizing strawberry with sodium hypochlorite, and peracetic acid.

Rocket leaf samples treated with hydrogen peroxide showed a significant difference in antioxidant capacity after treatment. Unlike in our study, Gutiérrez et al. (2015) used a different treatment, UV-C irradiation, and found that rocket leaves post-treatment showed significantly higher levels of antioxidant capacity ( $27 \%$ at the end of 12 days in storage) compared to control samples. Valiolahi et al. (2019) tested the sanitization process (acetic and lactic acid, and hydrogen peroxide) of basil leaves and observed losses in the total phenolic compounds content as well as antioxidant capacity. Vegetables and fruits, in particular, contain several antioxidant compounds, including ascorbic acid, phenolic compounds, carotenoids, and polyphenols (Leong \& Shui, 2002). The reduction of ascorbic acid in rocket samples can affect the decrease of antioxidant capacity. There are indications of a strong positive relationship between these compounds and the antioxidant capacity of fruits and vegetables (Valiolahi et al., 2019). 


\section{Conclusion}

The proposed treatments promoted maintenance of physicochemical characteristics of strawberries, cucumbers, and rocket leaves. This result indicates the potential of these proposed treatments to be used to sanitize fruits and vegetables. It is worth noting that in previous studies, these same treatments presented similar or superior performances in deteriorating and pathogenic microbiota reduction compared to chlorinated compounds. These results suggest that all non-chlorinated sanitizers used in this study can contribute to vegetable safety and quality.

\section{Acknowledgements}

The authors gratefully acknowledge the Foundation for the Support of Research and Innovation of Espírito Santo (FAPES) for financial support for the project number 554/2015 approved on Edital Fapes no. 006/2014. We thank FAPES and Conselho Nacional de Desenvolvimento Científico e Tecnológico (CNPq/Brasil) for the scientific initiation scholarship, at the time of conducting the research of the first and third author's, respectively. We thank Coordenação de Aperfeiçoamento de Pessoal de Nível Superior (CAPES) and Fundo de Apoio à Pesquisa da Universidade Federal do Espírito Santo (FAP/UFES) for all the support.

\section{References}

Alexandre, E. M. C., Brandão, T. R. S., \& Silva, C. L. M. (2012). Assessment of the impact of hydrogen peroxide solutions on microbial loads and quality factors of red bell peppers, strawberries and watercress. Food Control, 27(2), 362-368. http://dx.doi.org/10.1016/j. foodcont.2012.04.012.

Argenta, G., Silva, P. D., Bortolini, C. G., Forsthofer, E. L., \& Strieder, M. L. (2001). Relação da leitura do clorofilômetro com os teores de clorofila extraível e de nitrogênio na folha de milho. Revista Brasileira de Fisiologia Vegetal, 13(2), 158-167. http://dx.doi.org/10.1590/ S0103-31312001000200005.

Association of Official Analytical Chemists - AOAC. (1997). Official methods of analysis of the AOAC. Washington: AOAC.

Blois, M. S. (1958). Antioxidant determinations by the use of a stable free radical. Nature, 181(4617), 1199-1200. http://dx.doi. org/10.1038/1811199a0.

Brand-Williams, W., Cuvelier, M. E., \& Berset, C. (1995). Use of a free radical method to evaluate antioxidant activity. LebensmittelWissenschaft + Technologie, 28(1), 25-30. http://dx.doi.org/10.1016/ S0023-6438(95)80008-5.

Dewhirst, R. A., Clarkson, G. J., Rothwell, S. D., \& Fry, S. C. (2017). Novel insights into ascorbate retention and degradation during the washing and post-harvest storage of spinach and other salad leaves. Food Chemistry, 233(15), 237-246. http://dx.doi.org/10.1016/j. foodchem.2017.04.082. PMid:28530571.

Feitosa, T., Garruti, D. S., Lima, J. R., Mota, S., Bezerra, F. M. L., Aquino, B. F., \& Santos, A. B. (2009). Qualidade de frutos de melancia produzidos com reúso de água de esgoto doméstico tratado. Revista de Tecnologia, 30(1),53-60.

Fernandes, G. R. (2013). Sanitizantes alternativos na qualidade microbiológica, física e química de morangos (Fragaria x Ananassa Duch) minimamente processado (Ph.D. thesis). Pós-Graduação em Ciência e Tecnologia de Alimentos, Universidade Federal de Viçosa.
Gutiérrez, D. R., Char, C., Escalona, V. H., Chaves, A. R., \& Rodríguez, S. D. C. (2015). Application of UV-C radiation in the conservation of minimally processed rocket (Eruca sativa Mill). Journal of Food Processing and Preservation, 39(6), 3117-3127. http://dx.doi. org/10.1111/jfpp.12577.

Instituto Adolfo Lutz. (2008). Métodos químicos e físicos para análise de alimentos. São Paulo, SP: Instituto Adolfo Lutz.

Karaca, H., \& Velioglu, Y. S. (2014). Effects of ozone treatments on microbial quality and some chemical properties of lettuce, spinach, and parsley. Postharvest Biology and Technology, 88, 46-53. http:// dx.doi.org/10.1016/j.postharvbio.2013.09.003.

Leong, L. P., \& Shui, G. (2002). An investigation of antioxidant capacity of fruit in Singapore markets. Food Chemistry, 76(1), 69-75. http:// dx.doi.org/10.1016/S0308-8146(01)00251-5.

Lopez, M. E., Gontijo, M. T., Boggione, D. M., Albino, L. A., Batalha, L. S., \& Mendonça, R. C. (2018). Microbiological contamination in foods and beverages: Consequences and alternatives in the era of microbial resistance. In A. M. Holban \& A. M. Grumezescu. Microbial Contamination and Food Degradation (pp. 49-84). New York: Academic Press. http://dx.doi.org/10.1016/B978-0-12-8115152.00003-2.

Martínez-Sánchez, A., Allende, A., Bennett, R. N., Ferreres, F., \& Gil, M. I. (2006). Microbial, nutritional and sensory quality of rocket leaves as affected by different sanitizers. Postharvest Biology and Technology, 42(1), 86-97. http://dx.doi.org/10.1016/j.postharvbio.2006.05.010.

Mishra, V., Abrol, G. S. \& Dubey, N. (2018). Sodium and calcium hypochlorite as postharvest disinfectants for fruits and vegetables. In M. W. Siddiqui. Postharvest disinfection of fruits and vegetables (pp. 253-272). New York: Academic Press.

Musa, C. I., Weber, B., Gonzatti, H. C., Biguelini, C. B., Souza, C. F. V., \& Oliveira, E. C. (2015). Avaliação do teor de Vitamina C em morangos de diferentes cultivares em sistemas de cultivo distintos no município de Bom Princípio/RS. Ciência e Natura, 37(2), 368 373. http://dx.doi.org/10.5902/2179460X16810.

Nguyen, T. V., Ross, T., \& Van Chuyen, H. (2019). Evaluating the efficacy of three sanitizing agents for extending the shelf life of fresh-cut baby spinach: food safety and quality aspects. AIMS Agriculture and Food, 4(2), 320-339. http://dx.doi.org/10.3934/agrfood.2019.2.320.

Nicolau-Lapeña, I., Abadias, M., Bobo, G., Aguiló-Aguayo, I., Lafarga, T., \& Viñas, I. (2019). Strawberry sanitization by peracetic acid washing and its effect on fruit quality. Food Microbiology, 83, 159166. http://dx.doi.org/10.1016/j.fm.2019.05.004. PMid:31202407.

Nogales-Delgado, S. N., Fernandéz-León, A. M., Delgado-Adámez, J., Hernández-Méndez, M. T., \& Bohoyo Gil, D. (2013). Effects of several sanitisers for improving quality attributes of minimally processed Fragaria vesca Strawberry. Czech Journal of Food Sciences, 31(1), 49-54. http://dx.doi.org/10.17221/378/2011-CJFS.

Park, E. J., Alexander, E., Taylor, G. A., Costa, R., \& Kang, D. H. (2009). The decontaminative effects of acidic electrolyzed water for Escherichia coli O157:H7, Salmonella Typhimurium, and Listeria monocytogenes on green onions and tomatoes with differing organic demands. Food Microbiology, 26(4), 386-390. http://dx.doi.org/10.1016/j. fm.2008.10.013. PMid:19376459.

Park, M. H., \& Kim, J. G. (2015). Low-dose UV-C irradiation reduces the microbial population and preserves antioxidant levels in peeled garlic (Allium sativum L.) during storage. Postharvest Biology and Technology, 100(1), 109-112. http://dx.doi.org/10.1016/j. postharvbio.2014.09.013.

Ranjitha, K., Sudhakar Rao, D. V., Shivashankara, K. S., \& Roy, T. K. (2018). Integrating calcium chloride treatment with polypropylene packaging improved the shelf life and retained the quality profile 
of minimally processed cabbage. Food Chemistry, 256, 1-10. http:// dx.doi.org/10.1016/j.foodchem.2018.02.012. PMid:29606423.

Reis, K. C., Siqueira, H. H., Alves, A. P., Silva, J. D., \& Lima, L. C. O. (2008). Efeito de diferentes sanificantes sobre a qualidade de morango cv. Oso Grande. Ciência e Agrotecnologia, 32(1), 196-202. http:// dx.doi.org/10.1590/S1413-70542008000100029.

Rico, D., Martín-Diana, A. B., Barat, J. M., \& Barry-Ryan, C. (2007). Extending and measuring the quality of fresh-cut fruit and vegetables: a review. Trends in Food Science \& Technology, 18(7), 373-386. http:// dx.doi.org/10.1016/j.tifs.2007.03.011.

Rosário, D. K. A., Silva Mutz, Y., Peixoto, J. M. C., Oliveira, S. B. S., Carvalho, R. V., Carneiro, J. C. S., São José, J. F. B., \& Bernardes, P. C. (2017). Ultrasound improves chemical reduction of natural contaminant microbiota and Salmonella enterica subsp. Enterica on strawberries. International Journal of Food Microbiology, 241, 23-29. http://dx.doi.org/10.1016/j.ijfoodmicro.2016.10.009. PMid:27743521.

Rosário, D. K., Duarte, A. L. A., Madalao, M., Libardi, M. C., Teixeira, L. J., Conte-Junior, C. A., \& Bernardes, P. C. (2018). Ultrasound Improves Antimicrobial Effect of Sodium Hypochlorite and Instrumental Texture on Fresh-Cut Yellow Melon. Journal of Food Quality, 2018, 1-6. http://dx.doi.org/10.1155/2018/2936589.

São José, J. F. B., \& Vanetti, M. C. D. (2015). Application of ultrasound and chemical sanitizers to watercress, parsley and strawberry: Microbiological and physicochemical quality. LebensmittelWissenschaft + Technologie, 63(2), 946-952. http://dx.doi.org/10.1016/j. lwt.2015.04.029.

São José, J. F. B., Medeiros, H. S., Bernardes, P. C., \& Andrade, N. J. (2014). Removal of Salmonella enterica Enteritidis and Escherichia coli from green peppers and melons by ultrasound and organic acids. International Journal of Food Microbiology, 190, 9-13. http://dx.doi. org/10.1016/j.ijfoodmicro.2014.08.015. PMid:25173914.

Shahbaz, H. M., Kim, J. U., Kim, S.-H., \& Park, J. (2018). Advances in nonthermal processing technologies for enhanced microbiological safety and quality of fresh fruit and juice products. In Food Processing for Increased Quality and Consumption (pp. 179-217). New York: Academic Press. http://dx.doi.org/10.1016/B978-0-12811447-6.00007-2.
Silva, J. M. D., Ongarelli, M. G., Del Aguila, J. S., Sasaki, F. F., \& Kluge, R. A. (2007). Métodos de determinação de clorofila em alface e cebolinha minimamente processadas. Revista Iberoamericana de Tecnología Postcosecha, 8(2), 53-59.

Silveira, L. O., do Rosário, D. K. A., Giori, A. C. G., Oliveira, S. B. S., Silva Mutz, Y., Marques, C. S., Coelho, J. M., \& Bernardes, P. C. (2018). Combination of peracetic acid and ultrasound reduces Salmonella Typhimurium on fresh lettuce (Lactuca sativa L. var. crispa). Journal of Food Science and Technology, 55(4), 1535-1540. http://dx.doi.org/10.1007/s13197-018-3071-8. PMid:29606768.

Singh, A., Walia, D., \& Batra, N. (2018). Fresh-Cut Fruits: Microbial degradation and preservation. In A. M. Holban \& A. M. Grumezescu. Microbial contamination and food degradation (pp. 149-176). New York: Academic Press.

Singleton, V. L., Orthofer, R., \& Lamuela-Raventós, R. M. (1999). Analysis of total phenols and other oxidation substrates and antioxidants by means of Folin-Ciocalteu reagent. Methods in Enzymology, 299, 152-177. http://dx.doi.org/10.1016/S0076-6879(99)99017-1.

Suarez, M. H., Rodriguez, E. M. R., \& Romero, C. D. (2008). Chemical composition of tomato (Lycopersicon esculentum) from Tenerife, the Canary Islands. Food Chemistry, 106(3), 1046-1056. http://dx.doi. org/10.1016/j.foodchem.2007.07.025.

Tian, J., Bae, Y., \& Lee, S. (2013). Survival of foodborne pathogens at different relative humidities and temperatures and the effect of sanitizers on apples with different surface conditions. Food Microbiology, 35(1), 21-26. http://dx.doi.org/10.1016/j.fm.2013.02.004. PMid:23628610.

Valiolahi, M., Najafi, M. A., Eskandani, M. A., \& Rahnama, M. (2019). Effects of organic acid alone and in combination with $\mathrm{H}_{2} \mathrm{O}_{2}$ and $\mathrm{NaCl}$ on Escherichia coli O157:H7: An evaluation of antioxidant retention and overall acceptability in Basil leaves (Ocimum basilicum). International Journal of Food Microbiology, 292, 56-63. http://dx.doi. org/10.1016/j.ijfoodmicro.2018.12.010. PMid:30576940.

Zhang, J., \& Yang, H. (2017). Effects of potential organic compatible sanitisers on organic and conventional fresh-cut lettuce (Lactuca sativa Var. Crispa L). Food Control, 72, 20-26. http://dx.doi.org/10.1016/j. foodcont.2016.07.030. 